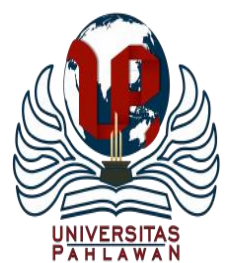

Edukatif : Jurnal Ilmu Pendidikan Volume 3 Nomor 5 Tahun 2021 Halm 2638 - 2651

EDUKATIF: JURNAL ILMU PENDIDIKAN

Research \& Learning in Education

https://edukatif.org/index.php/edukatif/index

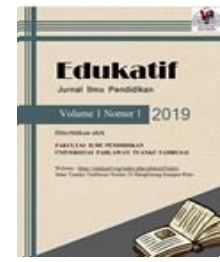

\title{
Pengembangan Media Video Tutorial Pembelajaran Mikrokontroler Arduino pada Mata Pelajaran Teknik Pemrograman Mikroprosesor dan Mikrokontroler di SMK
}

\author{
Galih Kresna Yoga Arlingga ${ }^{1 凶}$, Arif Widodo \\ Universitas Negeri Surabaya, Indonesia ${ }^{1,2}$

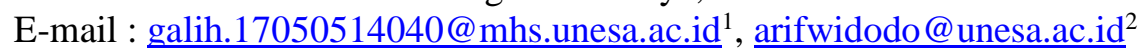

\begin{abstract}
Abstrak
Selama masa pandemi covid-19 kegiatan pembelajaran secara langsung menjadi semakin berkurang, yang akhirnya menyebabkan peserta didik kurang memahami materi yang diberikan. Karena itu, tujuan penelitian ini adalah menghasilkan sebuah media belajar jarak jauh berupa video tutorial mikrokontroler arduino pada mata pelajaran teknik pemrograman, mikroprosesesor dan mikrokontroler dengan mengnalisis tingkat kevalidan, kepraktisan dan keefektifan dalam upaya meningkatkan hasil belajar peserta didik. Pengembangan media pada penelitian ini menggunakan tahapan ADDIE dengan desain penelitian yang digunakan yaitu One Group Pretest-Postest. Hasil penelitian ini didapatkan nilai hasil rating validasi pada aspek media dan aspek materi secara berurutan diperoleh nilai persentase $85 \%$ dan $86 \%$ dengan kategori sangat valid. Untuk tingkat kepraktisan didapatkan dari angket respon siswa dengan rata-rata nilai persentase adalah $86 \%$ dengan kategori sangat praktis. Untuk tingkat efektifitas dengan analisa software SPSS didapatkan nilai asymp. sig lebih kecil dari $0,05(0,000<0,05)$, maka ada pengaruh yang signifikan penggunaan media video tutorial pembelajaran mikrokontroler arduino terhadap hasil belajar peserta didik. Dengan ini dapat disimpulkan bahwa penggunaan media video tutorial pembelajaran mikrokontroler arduino layak digunakan untuk meningkatkan hasil belajar peserta didik.
\end{abstract}

Kata Kunci: Video, ADDIE, Pretest-Postest.

\begin{abstract}
During the covid-19 pandemic, learning activities directly become reduced, which eventually causes students to lack understanding of the materials provided. Therefore, the purpose of this study is to produce a medium of distance learning in the form of video tutorials arduino microcontrollers in the subjects of programming techniques, microprosesesor and microcontroller by analyzing the level of validity, practicality and effectiveness in an effort to improve the learning outcomes of learners. Media development in this study uses ADDIE stage with research design used namely One Group Pretest-Postest. The results of this study obtained validation rating results on media aspects and material aspects sequentially obtained percentage values of $85 \%$ and $86 \%$ with a very valid category. For the level of practicality obtained from the questionnaire of student response with an average percentage score is $86 \%$ with a very practical category. For the level of practicality obtained from the questionnaire of student response with an average percentage score is $86 \%$ with a very practical category. For the level of effectiveness with spss software analysis obtained asymp value. sig is smaller than $0.05(0.000<0.05)$, then there is a significant influence on the use of video tutorial media arduino microcontroller learning on student learning outcomes. With this it can be concluded that the use of video tutorial media arduino microcontroller learning is worth using to improve the learning outcomes of learners.
\end{abstract}

Keywords: Video, ADDIE, Pretest-Postest

Copyright (c) 2021 Galih Kresna Yoga Arlingga, Arif Widodo

$\triangle$ Corresponding author

Email : galih.17050514040@mhs.unesa.ac.id

DOI : https://doi.org/10.31004/edukatif.v3i5.866

ISSN 2656-8063 (Media Cetak)

ISSN 2656-8071 (Media Online)

Edukatif : Jurnal Ilmu Pendidikan Vol 3 No 5 Tahun 2021 p-ISSN 2656-8063 e-ISSN 2656-8071 
2639 Pengembangan Media Video Tutorial Pembelajaran Mikrokontroler Arduino pada Mata Pelajaran Teknik Pemrograman Mikroprosesor dan Mikrokontroler di SMK - Galih Kresna Yoga Arlingga, Arif Widodo DOI: https://doi.org/10.31004/edukatif.v3i5.866

\section{PENDAHULUAN}

Pandemi covid-19 merupakan wabah yang tidak bisa dipungkiri membawa dampak yang besar bagi Indonesia. Dampak tersebut dapat dilihat diberbagai sektor mulai dari ekonomi sampai dengan pendidikan. Dari sektor ekonomi menurut penelitian (Arianto, 2021) pandemi covid-19 mengakibatkan menurunnya perekonomian di Indonesia khususnya dari sisi perdagangan, pariwisata, dan investasi. Pada sektor pendidikan sudah sangat jelas mengganggu, karena peraturan untuk belajar dari rumah jelas membuat rintangan yang besar, seperti pembelajaran yang kurang, penilaian sulit, pembatalan penilaian, sulit mendapat pekerjaan setelah lulus, dan sulitnya kualifikasi penilaian masyarakat dalam seleksi pekerjaan (Syah, 2020).

Dengan ditetapkannya kebijakan untuk belajar di rumah, sebenarnya juga sebagai langkah untuk mengurangi penyebaran virus covid-19 (Saleh, n.d.). Secara garis besar permasalah pada sektor pendidikan adalah tidak terhubungnya pendidik dan peserta didik dengan bertatap muka secara langsung. Dari permasalahan tersebut dapat dilihat bahwa sebuah media pembelajaran jarak jauh sangat dibutuhkan untuk menunjang pembelajaran (Jusuf et al., 2020). Menurut penelitian (Abidin et al., 2020) bahwa proses pembelajaran jarak jauh cukup efektif dilaksanakan dalam kondisi seperti sekarang, meskipun juga memiliki kelemahan. Menurut penelitian (Yuangga \& Sunarsi, 2020) kelemahan pendidikan jarak jauh adalah peserta didik tidak akan dapat konsentrasi belajar saat berada di rumah. Selain itu, kelemahan pembelajaran jarak jauh juga adalah masalah kekuatan sinyal yang berbeda di berbagai tempat (Yensy, 2020). Sitem pembelajaran jarak jauh mempunyai beberapa ciri diantaranya adalah pendidik dan peserta didik terpisah, pengaruh lembaga pendidikan, penggunaan media penghubung pendidik dan peserta didik, berlangsungnya komunikasi, memperhatikan peserta didik, dan merupakan suatu industri (Kahfi, 2020).

Dari hasil observasi di lapangan bahwa proses pembelajaran di jurusan TEI SMKN 1 Driyorejo selama masa pandemi covid-19 pemberian materi dan tugas hanya disampaikan melalui learning management system (LMS) seperti Mobo. Kondisi seperti ini menjadikan bimbingan guru kepada peserta didik semakin terbatas dan berkurang yang menyebabkan sulitnya pemahaman peserta didik terhadap materi yang diberikan (Siahaan, 2020). Bukti bahwa peserta didik sulit untuk memahami materi yang diberikan adalah pada saat ada sesi tanya jawab secara langsung dan hasil ujian pada mata pelajaran teknik pemrograman mikroprosesor dan mikrokontroler yang tidak memenuhi kriteria ketuntasan minimal atau KKM. Selain itu, permasalahan yang terjadi juga adalah kurangnya peserta didik untuk melakukan praktikum secara langsung. Pembelajaran praktik dapat berlangsung apabila peserta didik melakukan pembelajaran jarak jauh dengan praktik mandiri di rumah.

Oleh sebab itu dari permasalahan tersebut menunjukkan bahwa diperlukan sebuah solusi untuk menaikkan pemahaman peserta didik dalam memahami mata pelajaran teknik pemrograman mikroprosesor dan mikrokontroler. Solusi dari permasalahan tersebut adalah dapat dibuatkan dan diterapkan sebuah media pembelajaran jarak jauh yang mudah dipahami dan sistematis untuk mata pelajaran teknik pemrograman mikroprosesor dan mikrokontroler. Dari penelitian yang sudah ada, penelitian yang mengangkat tentang pembelajaran mikrokontroler secara jarak jauh hanya berupa aplikasi android, modul dan jobsheet. Salah satu contoh penelitian yang membahas tentang mikrokontroler adalah penelitian yang dilakukan oleh (Syawal, 2021) yang membuat sebuah modul pembelajaran mikrokontroler berbasis online.

Berdasarkan latar belakang tersebut, perbedaan dari penelitian sebelumnya yaitu belum adanya penelitian yang mengembangkan sebuah video tutorial sebagai media pembelajaran jarak jauh untuk materi mikrokontroler, maka dikembangkan penelitian yang berjudul "Pengembangan Media Video Tutorial Pembelajaran Mikrokontroler Arduino pada Mata Pelajaran Teknik Pemrograman Mikroprosesor dan Mikrokontroler di SMK". Video tutorial pembelajaran dipilih karena ada beberapa alasan yang mendasari diantaranya: (1) melihat kondisi sekarang ini yang mengharuskan untuk melakukan pembelajaran secara jarak jauh, (2) video adalah media yang menyenangkan dan bisa membangkitkan rasa ingin tahu serta membuat 
peserta didik antusias terhadap pembelajaran (Irfan, A., 2016), (3) video bisa menguraikan sesuatu yang bersifat mujarat menjadi seperti nyata (Pebriani, 2017), (4) sebuah video mempunyai daya tarik tersendiri bagi peserta didik (Hadi, 2017). Selain itu, video juga mudah untuk diakses dimanapun dan kapanpun berada dengan menggunakan smartphone.

Dasar lain yang menjadi pembeda dari video pembelajaran pada penelitian-penelitian sebelumnya adalah video pembelajaran tersebut diterapkan pada masa pandemi dengan metode pembelajaran jarak jauh. Selain itu, pengambilan video akan diambil dari atas atau overhead camera yang belum ada penelitian mengenai video tutorial menggunakan teknik tersebut. Karenanya tujuan dari penelitian pengembangan video tutorial ini adalah mengembangkan media pembelajaran mikrokontroler arduino yang dapat meningkatkan pmahaman peserta didik pada mata pelajaran teknik pemrograman mikroprosesor dan mikrokontroler.

\section{METODE PENELITIAN}

Pada pelaksanaanya penelitian ini dilakukan di SMKN 1 Driyorejo tahun ajaran 2020/2021 dengan sampel penelitian ini adalah pada kelas X TEI dengan jumlah 66 peserta didik. Populasi pada penelitian ini yaitu peserta didik kelas X TEI SMKN 1 Driyorejo. Pengambilan sampel penelitian ini menggunakan teknik probability sampling dengan jenis sampel acak dengan cara pengambilan sampel tanpa memperhatikan strata dalam populasi tersebut.

Penelitian dilakukan ini menggunakan jenis penelitian pengembangan dengan tahapan ADDIE (Analyze, Design, Development, Implementation and Evaluation). Menurut (Cheung, 2016) menyatakan bahwa jenis penelitian $A D D I E$ adalah jenis penelitian yang mudah digunakan dan diterapkan dalam kurikulum yang mengajarkan pengetahuan, keterampilan ataupun sikap.

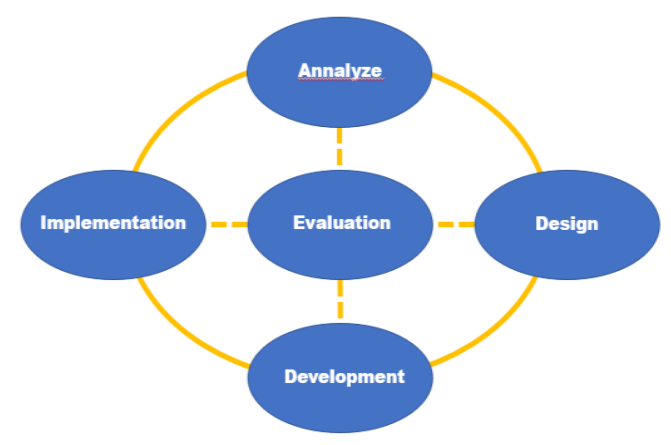

Gambar 1. Tahapan Penelitian ADDIE

(Sumber: Branch: 2009)

Desain yang digunakan dalam penelitian ini adalah One Group Pretest-Posttest. Penelitian ini mempunyai alur yaitu sebelum peserta didik diberikan perlakuan $(\mathrm{X})$ dalam hal ini adalah sebuah media video tutorial pembelajaran mikrokontroler arduino, akan diberikan terlebih dahulu sebuah pretest atau tes awal $\left(\mathrm{O}_{1}\right)$. Setelah diberikan perlakuan $(\mathrm{X})$ berupa media video tutorial pembelajaran mikrokontroler arduino barulah peserta didik diberi lagi sebuah posttest atau tes akhir $\left(\mathrm{O}_{2}\right)$.

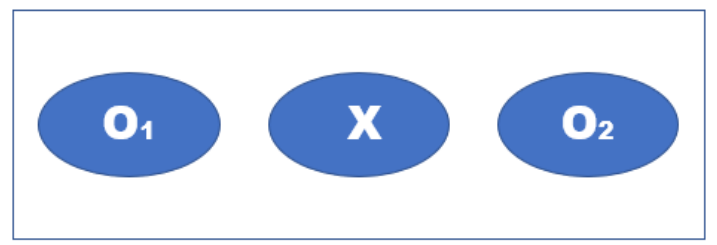

Gambar 2. Desain Penelitian One Group Pretest-Posttest

(Sumber: Sugiyono, 2015) 
2641 Pengembangan Media Video Tutorial Pembelajaran Mikrokontroler Arduino pada Mata Pelajaran Teknik Pemrograman Mikroprosesor dan Mikrokontroler di SMK - Galih Kresna Yoga Arlingga, Arif Widodo

DOI: https://doi.org/10.31004/edukatif.v3i5.866

Keterangan:

$\mathrm{O}_{1}$ : Tes awal (pretest) dilakukan sebelum diberi media video tutorial pembelajaran mikrokontroler arduino.

$\mathrm{X}$ : Perlakuan (media video tutorial pembelajaran mikrokontroler arduino)

O:Tes akhir (posttest) dilakukan setelah diberi media video tutorial pembelajaran mikrokontroler arduino.

Cara untuk mendapatkan data atau teknik pengumpulan data yang diinginkan adalah dengan menggunakan validasi ahli, angket untuk peserta didik dan pemberian soal tes. Instrumen yang digunakan untuk dapat memperoleh data-data tersebut antara lain lembar angket validasi ahli yang meliputi validasi ahli media dan ahli materi, lembar angken respon untuk peserta didik, dan lembar soal tes kompetensi pengetahuan berupa pretest dan postest.

Teknik analisis data yang digunakan pada penelitian ini adalah sebagai berikut. Analisis validitas dari media video tutorial pembelajaran yang diperoleh dari hasil penilaian lembar validasi oleh beberapa validator ahli yang berkompeten. Data tersebut akan akan diolah sesuai kriteria kevalidan dan ditarik kesimpulan. Analisis kepraktisan yang diperoleh dari angket yang diberikan kepada peserta didik dan akan akan diolah dengan kriteria kepraktisan lalu ditarik kesimpulan. Analisis efektifitas yang diperoleh dari pengujian soal kepada peserta didik dengan membandingkan nilai pretest dan posttest.

Untuk bobot penilaian pada analisis validitas dilakukan dengan memberi respon bobot penilaian berskala empat. Bobot penilaian validasi ahli dapat dilihat pada Tabel 1 berikut.

Tabel 1. Bobot Penilaian Lembar Validasi

Kriteria Penilaian Bobot Nilai

\begin{tabular}{ll}
\hline Sangat valid & 4 \\
\hline Valid & 3 \\
\hline Kurang valid & 2 \\
\hline Tidak valid & 1 \\
\hline (Sumber: Diadaptasi dari Riduwan, 2015)
\end{tabular}

Jumlah jawaban dari validator akan dikalikan dengan bobot nilainya lalu menjumlahkannya dengan rumus (1). Setelah dilakukan perhitungan tersebut maka langkah selanjutnya adalah menentukan hasil rating penilaian dengan rumus (2).

$$
\begin{array}{ll}
\text { Sangat valid } & =\mathrm{n} \times 4 \\
\text { Valid } & =\mathrm{n} \times 3 \\
\text { Kurang valid } & \mathrm{n} \times 2 \\
\text { Tidak valid } & \mathrm{n} \times 1 \\
\hline \begin{array}{ll}
\text { Skor validasi } & =\ldots \\
\text { (Sumber: Diadaptasi dari Sugiyono, 2015) }
\end{array} \\
\begin{array}{l}
\text { Keterangan: } \\
\mathrm{n}=\text { jumlah jawaban validator }
\end{array} \\
\begin{array}{l}
\text { Hasil Rating }(\mathrm{HR})=\frac{\sum \text { skor validator }}{\sum \text { skor maksimal }} \times 100 \% \\
\text { (Sumber: Sugiyono, 2015) }
\end{array}
\end{array}
$$

Jika sudah didapatkan nilai hasil rating pada setiap validator, nilai hasil rating selanjutnya dibuat ratarata untuk seluruh validator dan disesuaikan dengan taraf rating. Krieria penilaian validasi ahli dapat dilihat pada Tabel 2 berikut. 
2642 Pengembangan Media Video Tutorial Pembelajaran Mikrokontroler Arduino pada Mata Pelajaran Teknik Pemrograman Mikroprosesor dan Mikrokontroler di SMK - Galih Kresna Yoga Arlingga, Arif Widodo DOI: https://doi.org/10.31004/edukatif.v3i5.866

Tabel 2. Rating Tingkat Kevalidan

\begin{tabular}{ll}
\hline Klasifikasi Penilaian & Hasil Rating \\
\hline Sangat valid & $82 \%$ s.d $100 \%$ \\
\hline Valid & $63 \%$ s.d $81 \%$ \\
\hline Kurang valid & $44 \%$ s.d $62 \%$ \\
\hline Tidak valid & $25 \%$ s.d $43 \%$ \\
\hline (Sumber: Diadaptasi dari Widoyoko, 2014)
\end{tabular}

Kriteria penilaian untuk analisis kepraktisan yang ditinjau dari respon peserta didik dilakukan dengan memberi respon bobot penilaian berskala empat. Bobot penilaian respon peserta didik dapat dilihat pada Tabel 3 berikut.

\begin{tabular}{|c|c|}
\hline Kriteria Penilaian & Bobot Nilai \\
\hline Sangat baik & 4 \\
\hline Baik & 3 \\
\hline Kurang baik & 2 \\
\hline Tidak baik & 1 \\
\hline
\end{tabular}

Jumlah jawaban dari respon peseta didik akan dikalikan dengan bobot nilainya lalu menjumlahkannya dengan rumus (3). Setelah dilakukan perhitungan tersebut maka langkah selanjutnya adalah menentukan hasil rating penilaian dengan rumus (4).

$\begin{array}{ll}\text { Sangat baik } & =\mathrm{n} \times 4 \\ \text { Baik } & =\mathrm{n} \times 3 \\ \text { Kurang baik } & =\mathrm{n} \times 2 \\ \text { Tidak baik } & =\mathrm{n} \times 1+ \\ \text { Skor validasi } & =\ldots .\end{array}$

(Sumber: Diadaptasi dari Sugiyono, 2015)

Keterangan:

$\mathrm{n}=$ jumlah jawaban peserta didik

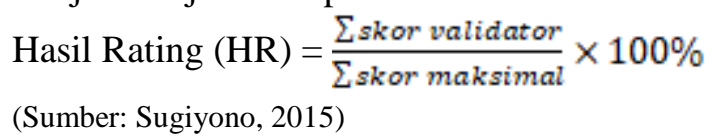

Jika sudah didapatkan nilai hasil rating pada setiap jawaban peserta didik, nilai hasil rating selanjutnya dibuat rata-rata untuk seluruh validator dan disesuaikan dengan taraf rating. Krieria penilaian respon peserta didik dapat dilihat pada Tabel 4 berikut.

Tabel 4. Rating Tingkat Kepraktisan

\begin{tabular}{ll}
\hline Klasifikasi Penilaian & Hasil Rating \\
\hline Sangat praktis & $82 \%$ s.d $100 \%$ \\
\hline Praktis & $63 \%$ s.d $81 \%$ \\
\hline
\end{tabular}


2643 Pengembangan Media Video Tutorial Pembelajaran Mikrokontroler Arduino pada Mata Pelajaran Teknik Pemrograman Mikroprosesor dan Mikrokontroler di SMK - Galih Kresna Yoga Arlingga, Arif Widodo DOI: https://doi.org/10.31004/edukatif.v3i5.866

\begin{tabular}{lc}
\hline Kurang praktis & $44 \%$ s.d $62 \%$ \\
\hline Tidak praktis & $25 \%$ s.d $43 \%$ \\
\hline (Sumber: Diadaptasi dari Widoyoko, 2014)
\end{tabular}

\section{HASIL DAN PEMBAHASAN PENELITIAN}

Hasil yang diperoleh dalam penelitian ini adalah sebuah media pembelajaran video tutorial mikrokontroler arduino pada mata pelajaran teknik pemrograman mikroprosesor dan mikrokontroler di SMKN 1 Driyorejo. Dalam jenis penelitian pengembangan degan tahapan ADDIE terdiri atas lima tahapan yaitu analyze, design, development, implementation and evaluation.

Tahap analyze, pada tahap ini yang dilakukan adalah menganalisis kebutuhan peserta didik dengan menyesesuaikan kondisi di sekolah. Tahap ini dilakukan dengan cara observasi yaitu mewawancarai guruguru di jurusan teknik elektronika industri SMKN 1 Driyorejo terkait permasalahan yang ada. Hal yang dianalisis adalah video yang dibuat harus sesuai dengan KD dan indikator yang ingin dicapai peserta didik. Selain itu, video yang dibuat harus sesuai dengan fasilitas yang sering dipakai di sekolah dan yang dimiliki peserta didik untuk sarana pembelajaran seperti proyektor ataupun smartphone. Dari observasi didapatkan informasi bahwa peserta didik hanya memperoleh pembelajaran secara satu arah. Pembelajaran hanya terfokus pada guru dan peserta didik tidak terlalu aktif di dalam kelas. Didapatkan informasi juga bahwa selama pandemi covid-19, pembelajaran praktik tidak dapat dilaksanakan di sekolah dan peserta didik hanya diberikan pranala dari youtube agar dapat belajar mandiri atau paling tidak bisa melihart proses praktikum walaupun sedang berada di rumah. Tetapi yang menjadi permasalahan adalah terkadang video yang ada di youtube kurang sesuai dengan indikator yang ingin dicapai. Maka dari permasalahan tersebut, media yang akan dikembangkan adalah berupa video tutorial pembelajaran mikrokontroler arduino pada mata pelajaran teknik pemrograman mikroprosesor dan mikrokontroler pada Kompetensi Dasar (KD) mengaplikasikan software untuk memprogram mikroprosesor dan mikrokontroler. Dalam tahap ini juga dilakukan analisis untuk mencari literatur yang relevan dengan penelitian yang dilakukan.

Tahap design, pada tahap ini yang dilakukan adalah merancang media seperti membuat flowchart pembuatan video sebagai gambaran alur pembuatan video. Selain flowchart yang perlu dirancang adalah mebuat storyboard alur setiap frame video yang akan ditampilkan. Dalam pembuatan flowchart video pembelajaran ini, diawali dengan persiapan yaitu menyusun materi dan bahan yang akan digunakan untuk membuat video seperti menulis skrip video sebagai acuan agar proses pembuatan video terarah. Dalam tahap perencanaan ini, video yang akan dibuat akan berdurasi \pm 5 menit. Selanjutnya adalah mencari reverensi gambar sebagai konten untuk membuat video, mencari reverensi video dan audio yang sesuai dengan yang diinginkan. Berkutnya adalah proses perekaman atau pengambilan video, pada proses ini video direkam dengan menggunakan kamera smartphone. Selain smartphone, peralatan lain yang digunakan untuk merekam adalah meja sebagai alas, tripod dan lighting. Dalam proses pengambilan video, dilakukan dari sudut $90^{\circ}$ atau tegak lurus dari meja atau overhead camera. Untuk jarak pengambilan gambarnya adalah medium close up. Setelah footage atau hasil rekaman sudah terkumpul, maka masuk pada proses editing. Proses editing ini sudah termasuk pada dalam tahap pengembangan atau development. Dalam proses editing yang dilakukan adalah mencari, memilih, memotong, memberi teks, memberi effect, memberi sound dan menggabungkan footage atau apapun untuk memperindah video. Setelah selesai proses editing, maka video akan diuji coba atau diujikan kepada beberapa validator ahli. Jika video bagus, maka lanjut pada proses upload pada youtube, tetapi jika setelah diujikan video kurang bagus maka akan diperbaiki lagi. Perbaikan video bisa pada saat proses perekaman atau pada saat proses editing. Flowchart pembuatan video dapat dilihat pada Gambar 2 berikut. 


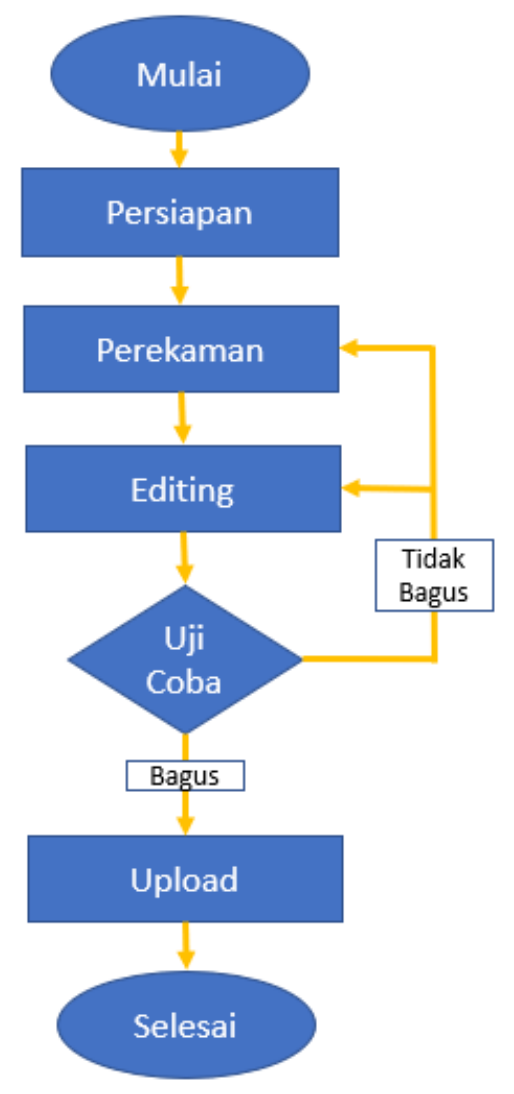

Gambar 3. Flowchard Pembuatan Video

Dalam tahap perancangan yang harus dilakukan selain membuat flowchart adalah membuat storyboard. Dalam pembuatan storyboard yang diperlukan hanya alat yang bisa digunakan untuk menggambar sketsa seperti kertas gambar dengan pensil atau juga bisa menggunakansebuah aplikasi menggambar pada komputer. Tujuan utama diperlukan storyboard adalah untuk menggambarkan atau memvisualisasikan alur setiap frame video yang akan ditampilkan sesuai dengan yang ada dalam pikiran. Untuk lebih jelasnya tentang storyboard akan diperlihatkan seperti Gambar 3 berikut.

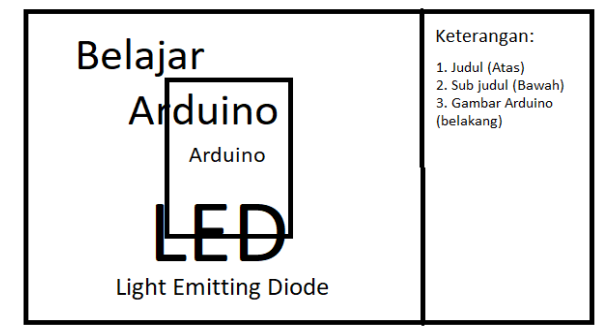

Gambar 4. Storyboard Pembuatan Video

Tahap development, pada tahap ini yang dilakukan adalah proses editing video. Software yang digunakan untuk proses editing, yaitu adobe premiere pro digunakan untuk mengolah video dan dibantu dengan corel draw yang digunakan untuk mengolah gambar. Proses editing juga dilakukan dengan beberapa tahapan. Pertama adalah melakukan revew footage hasil shooting untuk diseleksi footage yang akan diambil. Kedua adalah memotong footage sesuai dengan yang diperlukan. Ketiga adalah menggabungkan dan mengurutkan beberapa footage sesuai storyboard yang dibuat. Keempat adalah memberikan backsound yang tepat dan disesuaikan dengan ritme yang diinginkan. Kelima adalah memberikan effect, seperti transition effect, audio effect, motion effect. Terakhir adalah proses rendering, yaitu menyatukan seluruh proses editing 
2645 Pengembangan Media Video Tutorial Pembelajaran Mikrokontroler Arduino pada Mata Pelajaran Teknik Pemrograman Mikroprosesor dan Mikrokontroler di SMK - Galih Kresna Yoga Arlingga, Arif Widodo DOI: https://doi.org/10.31004/edukatif.v3i5.866

dan dijadikan dalam satu video. Proses editing yang dilakukan dapat dilihat pada Gambar 4 dan Gambar 5 berikut.

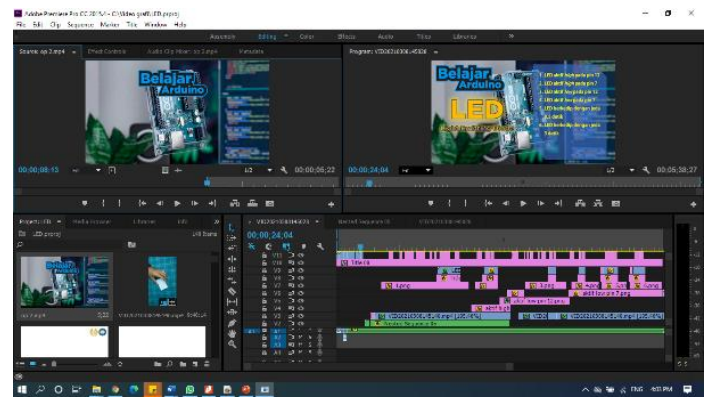

Gambar 5. Proses Editing Menggunakan Software Adobe Premiere Pro

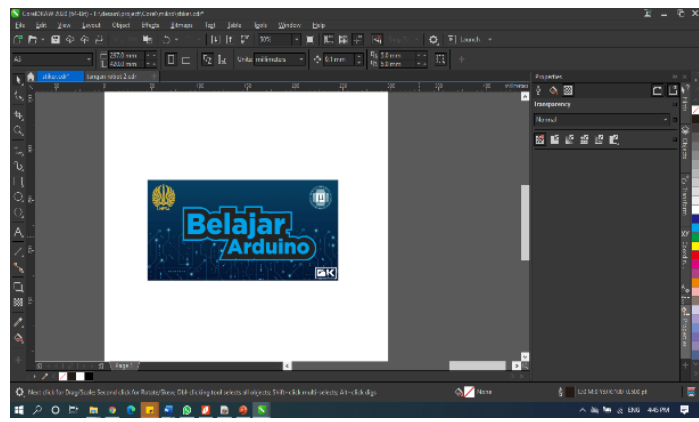

Gambar 6. Proses Editing Menggunakan Software Corel Draw

Tahap implementation, pada tahap ini adalah tahap media video tutorial pembelajaran mikrokontroler arduino sudah selesai dibuat. Disini akan disajikan beberapa frame seperti frame pembukaan video, frame praktikum apa saja yang akan dilaksanakan, frame alat dan bahan yang akan digunakan, frame skema rangkaian dan gambar rangkaian, frame gambar rangkaian dan cara merangkai, frame cara mengcoding, frame penutup video.

Pada video tutorial pembelajaran mikrokontroler arduino ini, untuk tampilan awal video disajikan pembukaan video sekaligus dilanjutkan dengan menampilkan judul serta bebrapa percobaan pembelajaran praktik yang akan dilakukan. Tujuan ditampilkanya frame tersebut adalah agar peserta didik mengetahui tujuan praktikum yang dilaksanakan. Berikut adalah frame awal setelah pembukaan video dari media video tutorial pembelajaran mikrokontroler arduino yang telah dikembangkan.

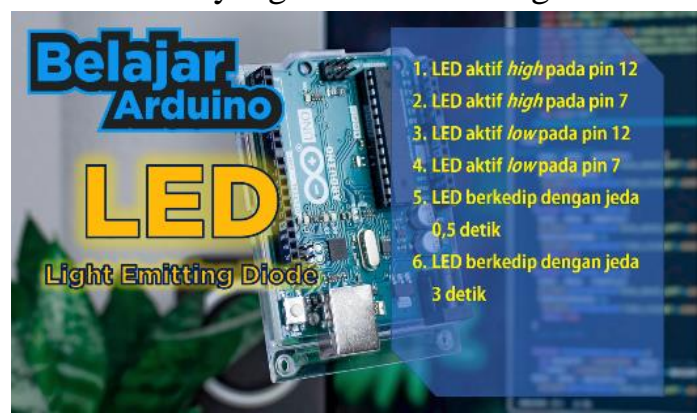

Gambar 7. Tampilan Praktikum yang Dilaksanakan

Pada frame berikutnya yang ditampilkan adalah alat dan bahan yang dibutuhkan pada saat praktik. Tujuan ditampilkannya frame tersebut adalah agar peserta didik mengetahui alat dan bahan apa saja yang dibutuhkan pada saat praktikum. Karena dengan mengetahui alat dan bahan yang dibutuhkan, peserta didik dapat mempersiapkan alat dan bahan praktikum terlebih dahulu. Untuk lebih jelasnya, frame yang ditampilkan adalah seperti Gambar 7 berikut. 


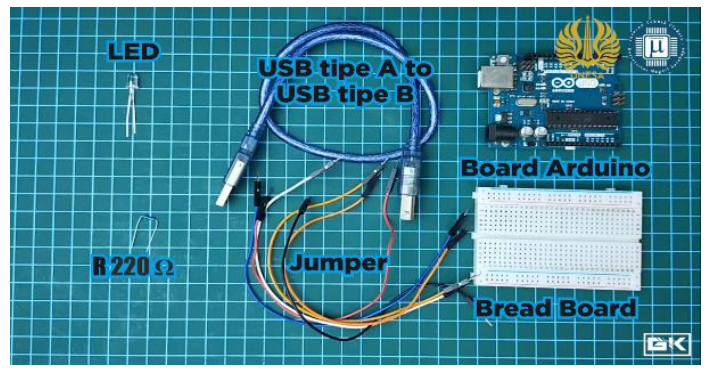

Gambar 8. Tampilan Alat dan Bahan yang Digunakan

Pada frame berikutnya adalah ditampilkan skema rangkaian dan gambar rangkaian. Tujuan dibuat frame tersebut adalah agar peserta didik dapat membayangkan bagaimana sebuah skema rangkaian yang direalisasikan dengan gambaran cara merangkainya. Skema rangkaian dibuat dengan menggunakan software proteus 8.7 yang ditampilkan pada sisi kiri. Gambaran rangkaian dibuat dengan menggunakan software fritzing yang ditampilkan pada sisi kanan. Untuk lebih jelasnya, frame yang ditampilkan adalah seperti Gambar 8 berikut.

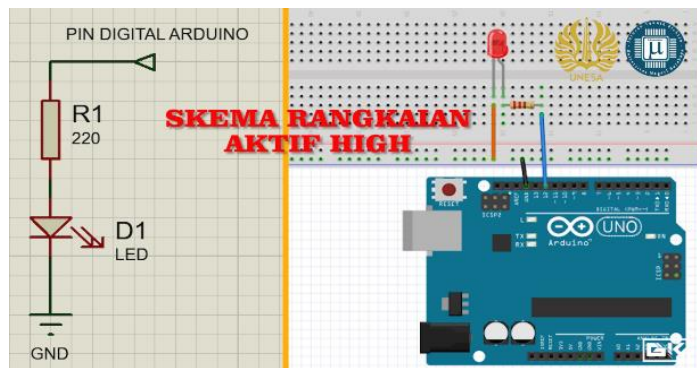

Gambar 9. Tampilan Skema Rangkaian dan Gambar Rangkaian

Pada frame berikutnya adalah ditampilkan gambar rangkaian dan video cara merangakai secara langsung. Tujuan dibuat frame tersebut adalah agar peserta didik dapat membandingkan antara gambar rangkaian dan bagaimana cara menyusun komponen secara langsung. Pada frame tersebut gambar rankaian ditampilkan pada sisi kiri dan video cara merangakai secara langsung ditampilkan pada sisi kanan. Untuk lebih jelasnya, frame yang ditampilkan adalah seperti Gambar 9 berikut.

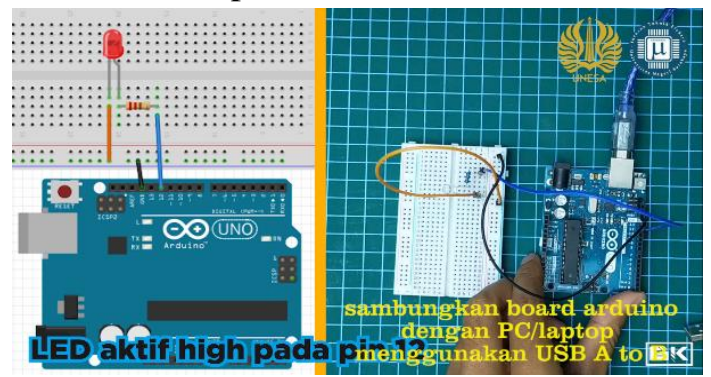

Gambar 10. Tampilan Gambar Rangkaian dan Cara Merangkai

Pada frame berikutnya adalah ditampilkan video cara memprogram pada software arduino IDE. Tujuan dibuat frame tersebut adalah agar peserta didik dapat mengikuti setiap langkah dalam memprogram sampai dengan mengunggah program pada rangkaian yang telah dibuat. Frame yang ditampilkan adalah seperti Gambar 10 berikut. 


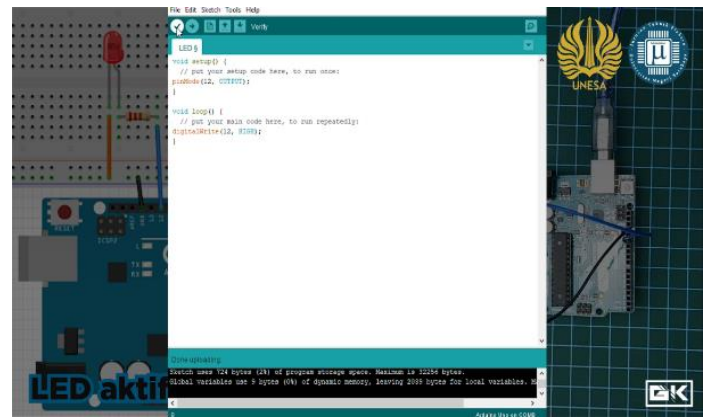

Gambar 11. Tampilan Cara Memprogram pada Software Arduino IDE

Pada tahap implementasi ini juga dilakukan uji validitas media video tutorial pembelajaran mikrokontroler arduino oleh beberapa ahli yang berkompeten. Para valiator ahli yang dipilih diantaranya adalah dua orang dosen dan satu orang guru untuk ahli media serta dua orang dosen dan satu orang guru untuk ahli materi. Hasil validitas media video tutorial pembelajaran mikrokontroler arduino ditunjukkan pada Tabel 5 berikut.

Tabel 5. Rating Hasil Rating Validasi

\begin{tabular}{ccc}
\hline \multirow{2}{*}{ Aspek } & Validator & Persentase \\
\hline \multirow{3}{*}{ Media } & Ahli Media 1 & $85 \%$ \\
\cline { 2 - 3 } & Ahli Media 2 & $75 \%$ \\
\cline { 2 - 3 } & Ahli Media 3 & $95 \%$ \\
\hline \multirow{3}{*}{ Materi } & Ahli Materi 1 & $86 \%$ \\
\cline { 2 - 3 } & Ahli Materi 2 & $81 \%$ \\
\cline { 2 - 3 } & Ahli Materi 3 & $90 \%$ \\
\hline
\end{tabular}

Dari Tabel 5 dapat diketahuai bahwa persentase hasil validasi media video tutorial pembelajaran mikrokontroler arduino dari ahli aspek media 1 adalah 85\%, dari ahli aspek media 2 adalah 75\%, dan ahli aspek media 3 adalah $95 \%$ dengan rata-rata persentase $85 \%$. Sedangkan dari ahli aspek materi 1 didapatkan persentase $86 \%$, dari ahli aspek materi 2 sebesar $81 \%$, dan dari ahli aspek materi 3 sebesar $90 \%$. Jika kedua aspek penilaian dihitung maka akan didapatkan persentase rata-rata nilai validasi adalah $85 \%$. Dengan begitu dapat disimpulkan bahwa media video tutorial pembelajaran mikrokontroler arduino dikategorikan sangat valid dan layak digunakan sebagai media pembelajaran. Hal ini sesuai dengan penelitian (Mutia \& Halim, 2017) tentang pengembangan video pembelajaran IPA yang validasi oleh 4 validator dan dikategorikan layak digunakan dalam pembelajaran. Didukung juga dengan penelitian (Febriantika et al., 2021) tentang kelayakan media video animasi untuk meningkatkan minat belajar.

Tahap evaluation, pada tahap evaluasi yang dilakukan adalah mengetahui kepraktisan dan keefektifan media video tutorial pembelajaran mikrokontroler arduino. Untuk menganalisis tingkat kepraktisan diukur dengan angket respon peserta didik yang diolah dengan kriteria kepraktisan. Untuk hasil rating respon peserta didik dapat dilihat pada Tabel 6 berikut.

Tabel 6. Rating Hasil Rating Respon Peserta Didik

Aspek Persentase

\begin{tabular}{ll}
\hline Materi & $91 \%$ \\
\hline Kemudahan & $91 \%$ \\
\hline Ketertarikan & $82 \%$ \\
\hline
\end{tabular}



Pemrograman Mikroprosesor dan Mikrokontroler di SMK - Galih Kresna Yoga Arlingga, Arif Widodo DOI: https://doi.org/10.31004/edukatif.v3i5.866

\begin{tabular}{ll} 
Gambar & $85 \%$ \\
\hline Warna & $82 \%$ \\
\hline Kecepatan & $81 \%$ \\
\hline Suara & $86 \%$ \\
\hline Bahasa & $88 \%$ \\
\hline Tulisan & $89 \%$ \\
\hline
\end{tabular}

Dari tabel 6 di atas dapat diketahuai bahwa data yang diperoleh dari hasil respon peserta didik terhadap media video tutorial pembelajaran mikrokontroler arduino. Pada aspek kesesuaian dengan materi didapatkan persentase sebesar $91 \%$, pada aspek kemudahan saat dipelajari didapatkan persentase sebesar $91 \%$, pada aspek ketertarikan untuk belajar arduino didapatkan persentase sebesar 82\%, pada aspek kesesuaian gambar yang dicantumkan dalam video didapatkan persentase sebesar 85\%, pada aspek kesesuaian warna yang digunakan dalam video didapatkan persentase sebesar $82 \%$, pada aspek kesesuaian kecepatan video didapatkan persentase sebesar $81 \%$, pada aspek kesesuaian suara dalam video didapatkan persentase sebesar $86 \%$, pada aspek bahasa yang digunakan didapatkan persentase sebesar $88 \%$, pada aspek kejelasan tulisan yang digunakan dalam video didapatkan persentase sebesar $89 \%$. Jika kesembilan aspek penilaian dirata-rata maka akan didapatkan nilai persentase sebesar $86 \%$. Dengan begitu dapat disimpulkan bahwa media video tutorial pembelajaran mikrokontroler arduino dikatgorikan sangat praktis sebagai sarana penunjang praktikum. Hal ini sesuai dengan penelitian dari (Ilsa et al., 2021) yang menyatakan video pembelajaran sangat praktis. Juga didukung dengan penelitian (Muthoharoh, 2021) yang mendapat persentase 89,18\% dengan kategori sangat baik.

Untuk menganalisis keefektifan media video tutorial pembelajaran mikrokontroler arduino adalah dengan memberikan pretest dan posttest kepada peserta didik. Pretest dan posttest digunakan untuk melihat pengaruh nilai sebelum dan sesudah diberikan perlakuan. Cara menganalisis efektifitas video tutorial pembelajaran mikrokontroler arduino sebelumnya harus dilakukan uji normalitas dan uji homogenitas variansi. Untuk menguji normalitas adalah dengan uji Kolmogorov-Smirnov, semetara untuk menguji homogenitas adalah dengan uji Levene. Uji normalitas digunakan agar dapat diketahui data berasal dari populasi yang berdistribusi normal atau tidak. Adapun uji normalitas menggunakan software IBM SPSS versi 26 diperoleh data seperti Tabel 7 berikut.

Tabel 7. Hasil Uji Normalitas Menggunakan Kolmogorov-Smirnov.

\begin{tabular}{llll}
\hline $\begin{array}{l}\text { Hasil Belajar } \\
\text { Siswa }\end{array}$ & Statistic & df & Sig. \\
\hline Pre Test & .095 & 66 & $.200^{*}$ \\
\hline Post Test & .141 & 66 & .002 \\
\hline
\end{tabular}

Berdasarkan penyajian hasil analisis SPSS pada Tabel 7 di atas, untuk uji normalitas distribusi didapatkan nilai signifikansi sebesar 0,200 untuk pretest dan 0,002 untuk posttest. Data ini menujukkan bahwa nilai pretest lebih besar dari $(\alpha) 0,05$ (sig $=0,200>0,05)$ sehingga $\mathrm{H} 0$ diterima dan $\mathrm{H} 1$ ditolak, dengan begitu dapat disimpulkan bahwa nilai pretest berasal dari populasi yang berdistribusi normal. Untuk nlai posttest lebih kecil dari $(\alpha) 0,05$ (sig $=0,002<0,05$ ) sehingga H0 ditolak dan H1 diterima, dengan begitu dapat disimpulkan bahwa nilai posttest berasal dari populasi yang tidak berdistribusi normal.

Untuk dapat diketahui data yang telah diperoleh homogen atau tidak, maka dilakukan uji homogenitas variansi. Uji homogenitas variansi dilakukan dengan menggunakan software SPSS seperti pada Tabel 8 berikut. 
2649 Pengembangan Media Video Tutorial Pembelajaran Mikrokontroler Arduino pada Mata Pelajaran Teknik Pemrograman Mikroprosesor dan Mikrokontroler di SMK - Galih Kresna Yoga Arlingga, Arif Widodo DOI: https://doi.org/10.31004/edukatif.v3i5.866

Tabel 8. Hasil Uji Homogenitas Variansi

\begin{tabular}{llll} 
Hasil Belajar Siswa & Levene Statistic & df2 & Sig. \\
\hline Based on Mean & 0,064 & 130 & 0,800 \\
\hline
\end{tabular}

Berdasarkan penyajian hasil analisis SPSS pada tabel 8 di atas, untuk uji homogenitas variansi diperoleh nilai $\mathrm{F}$ levene 0,064 dengan nilai signifikansi 0,800. Data ini menujukkan bahwa nilai signifikansi lebih besar dari $0,05(0,800<0,05)$ sehingga $\mathrm{H} 0$ diterima dan $\mathrm{H} 1$ ditolak. Maka dapat disimpulkan bahwa nilai pretest dan posttest pada mata pelajaran teknik pemrograman mikroprosesor dan mikrokontroler mempunyai variansi yang sama atau homogen.

Dikarenakan data yang diperoleh dari uji normalitas tidak berdistribusi normal, maka data dikatakan tidak memenuhi uji persyaratan untuk uji parametrik sehingga pengujian dilanjutkan menggunakan uji nonparamatrik yaitu uji Wilcoxon Signed-Rang Test. Data hasil uji Wilcoxon Signed-Rang Test menggunakan software SPSS dapat dilihat seperti pada Tabel 9 berikut.

Tabel 9. Hasil Uji Wilcoxon Signed-Rang Test

\begin{tabular}{ll}
\hline & Post Test - Pre Test \\
\hline $\mathrm{Z}$ & $-6.537^{\mathrm{b}}$ \\
\hline Asymp. Sig. (2-tailed) & .000 \\
\hline
\end{tabular}

Berdasarkan hasil analisis SPSS pada Tabel 9, niai $\mathrm{Z}_{\text {hitung }}=-6,537$ dengan nilai asymp. sig (2-taled $)=$ 0,000. Karena nilai asymp. sig lebih kecil dari 0,05 $(0,000<0,05)$ maka H0 ditolak dan H1 diterima, yang artinya ada perbedaan yang signifikan antara rata-rata hasil belajar pretest dan posttest. Degan demikian dapat diinterpretasikan bahwa terdapat perbedaan yang signifikan antara sebelum dan sesudah penggunaan media video tutorial pembelajaran mikrokontroler arduino terhadap hasil belajar peserta didik kelas $\mathrm{X}$ teknik elektronika industri di SMKN 1 Driyorejo. Maka media video tutorial pembelajaran mikrokontroler arduino dapat dinyatakan efektif digunakan dalam pembelajaran. Hal ini sesuai dengan penelitian dari (Sudarma, 2019) yang menyatakan video pembelajaran berorientasi pendidikan karakter efektif meningkatkan hasil belajar simulasi digital. Didukung juga dengan penelitian (Izzudin \& Suharmanto, 2013) yang menyatakan media video efektif untuk digunakan menjadi media pembelajaran untuk KD (Kompetensi Dasar) service engine dan komponen-komponennya (engine tune-up EFI).

Dengan demikian penelitian pengembangan media video tutorial yang diterapkan secara berbeda dari penelitian sebelumnya yaiti dapat digunakan sebagai media alternatif pembelajaran mikrokontroler arduino pada mata pelajaran teknik pemrograman mikroprosesor dan mikrokontroler saat kondisi pandemi yang mengharuskan untuk pembelajaran jarak jauh.

Dari pengujian yang terbatas memiliki beberapa keterbatasan penelitian ini yaitu, pengujian yang dilakukan hanya pada siswa SMK dan materi hanya menggunakan mikrokontroler arduino. Sehingga penelitian pengembangan media video tutorial ini masih perlu dilakukan pengujian yang lebih luas seperti kepada mahasiswa dan juga materi yang dikembangkan tidak hanya mikrokontroler arduino tetapi pada mikrokontroler lain. Penelitian ini juga bisa dikembangkan lagi pada mata pelajaran lain dengan metode pembelajaran yang sesuai keperluan.

\section{KESIMPULAN}

Berdasarkan penelitian yang telah dilaksanakan maka dapat disimpulkan sebagai berikut. Pertama, tingkat validitas video ditinjau dari aspek materi diperoleh hasil persentase rata-rata $86 \%$ dan dapat dikategorikan sangat valid. Pada aspek media diperoleh persentase rata-rata $85 \%$ dan dapat dikategorikan 
2650 Pengembangan Media Video Tutorial Pembelajaran Mikrokontroler Arduino pada Mata Pelajaran Teknik Pemrograman Mikroprosesor dan Mikrokontroler di SMK - Galih Kresna Yoga Arlingga, Arif Widodo DOI: https://doi.org/10.31004/edukatif.v3i5.866

sangat valid. Dari data tersebut dapat disimpulkan bahwa media video tutorial pembelajaran mikrokontroler arduino dikategorikan sangat valid. Kedua, tingkat kepraktisan video berdasarkan hasil analisis respon peserta didik dari sembilan aspek penilaian didapatkan persentase rata-rata $86 \%$. Maka dapat disimpulkan bahwa media video tutorial pembelajaran mikrokontroler arduino dikategorikan sangat praktis. Ketiga, tingkat efektifitas yang ditinjau dari hasil belajar peserta didik menunjukkan bahwa rata-rata hasil nilai asymp. sig (2taled $)=0,000$. Karena nilai 0,000 lebih kecil dari 0,05 $(0,000<0,05)$. Degan demikian dapat disimpulkan terdapat perbedaan yang signifikan antara sebelum dan sesudah penggunaan media video tutorial pembelajaran mikrokontroler arduino terhadap hasil belajar peserta didik kelas X teknik elektronika industri di SMKN 1 Driyorejo. Maka media video tutorial pembelajaran mikrokontroler arduino dapat dinyatakan efektif.

\section{DAFTAR PUSTAKA}

Abidin, Z., Hudaya, A., \& Anjani, D. (2020). Efektivitas Pembelajaran Jarak Jauh Pada Masa Pandemi Covid19. Research And Development Journal Of Education, $1(1), \quad 131$. Https://Doi.Org/10.30998/Rdje.V1i1.7659

Arianto, B. (2021). Dampak Pandemi COVID-19 Terhadap Perekonomian Dunia. Jurnal Ekonomi Perjuangan, 2(2), 212-224. Https://Doi.Org/10.36423/Jumper.V2i2.665

Cheung, L. (2016). Using The Addie Model Of Instructional Design To Teach Chest Radiograph Interpretation. Journal Of Biomedical Education, 2016, 1-6. Https://Doi.Org/10.1155/2016/9502572

Febriantika, F., Fisabilillah, N., \& Sakti, N. C. (2021). Edukatif: Jurnal Ilmu Pendidikan Pengembangan Video Animasi Sebagai Upaya Peningkatan Minat Belajar Peserta Didik Materi Perpajakan Di Sekolah Menengah Atas. 3(4), 1271-1281.

Hadi, S. (2017). Efektivitas Penggunaan Video Sebagai Media Pembelajaran Untuk Siswa Sekolah Dasar. Prosiding TEP \& Pds, 1(15), 96-102.

Ilsa, A., Farida, F., \& Harun, M. (2021). Pengembangan Video Pembelajaran Dengan Menggunakan Aplikasi Powerdirector 18 Di Sekolah Dasar. 5(1), 288-300.

Irfan, A., D. (2016). Perbedaan Media Audio Visual Dan Bukan Audio Visual Terhadap Motivasi Dan Hasil Belajar IPS Siswa Kelas IV. Wahana Sekolah Dasar (Kajian Teori Dan Praktik Pendidikan), 24(1), 1-8.

Izzudin, A. M., \& Suharmanto, A. (2013). Efektivitas Penggunaan Media Pembelajaran Video Interaktif Untuk Meningkatkan Hasil Belajar Praktik Service Engine Dan Komponen-Komponennya. Journal Unnes, 2(2), 1-8.

Jusuf, H., Sobari, A., \& Fathoni, M. (2020). Pengaruh Pembelajaran Jarak Jauh Bagi Siswa SMA Di Era Covid-19. Jurnal Kajian Ilmiah, 1(1), 15-24. Https://Doi.Org/10.31599/Jki.V1i1.212

Kahfi, A. (2020). Tantangan Dan Harapan Pembelajaran Jarak Jauh Di Masa Pandemi Covid 19. Dirasah, 03(2), 137-154. Https://Stai-Binamadani.E-Journal.Id/Jurdir

Muthoharoh, F. C. (2021). Edukatif: Jurnal Ilmu Pendidikan Pengembangan Media Pembelajaran Berbasis Video Naratif Dengan Metakognitif Pada Materi Ketenagakerjaan Fitria Cholifatoul Muthoharoh. 3(5), 2032-2039.

Mutia, R., \& Halim, A. (2017). Pengembangan Video Pembelajaran Ipa Pada Materi Pencemaran Dan Kerusakan Lingkungan. 5(2), 108-114. Https://Doi.Org/10.24815/Jpsi.V5i2.9825

Pebriani, C. (2017). Pengaruh Penggunaan Media Video Terhadap Motivasi Dan Hasil Belajar Kognitif Pembelajaran IPA Kelas V. Jurnal Prima Edukasia, 5(1), 11-21. Https://Doi.Org/10.21831/Jpe.V5i1.8461

Saleh, A. M. (N.D.). Problematika Kebijakan Pendidikan Di Tengah Pandemi Dan Dampaknya Terhadap 
2651 Pengembangan Media Video Tutorial Pembelajaran Mikrokontroler Arduino pada Mata Pelajaran Teknik Pemrograman Mikroprosesor dan Mikrokontroler di SMK - Galih Kresna Yoga Arlingga, Arif Widodo DOI: https://doi.org/10.31004/edukatif.v3i5.866

Proses Pembelajaran Di Indonesia.

Siahaan, M. (2020). Dampak Pandemi Covid-19 Terhadap Dunia Pendidikan. Jurnal Kajian Ilmiah, 1(1), 73 80. Https://Doi.Org/10.31599/Jki.V1i1.265

Sudarma, I. K. (2019). Pengembangan Media Video Pembelajaran Berorientasi Pendidikan Karakter. 3(20), $140-146$.

Syah, R. H. (2020). Dampak Covid-19 Pada Pendidikan Di Indonesia: Sekolah, Keterampilan, Dan Proses Pembelajaran. SALAM: Jurnal Sosial Dan Budaya Syar-I, 7(5). Https://Doi.Org/10.15408/Sjsbs.V7i5.15314

Syawal, I. (2021). Pengembangan Modul Pembelajaran Mikrokontroler Berbasis Online Untuk Mahasiswa Teknik Elektro. 02(01), 1-5.

Yensy, N. A. (2020). Efektifitas Pembelajaran Statistika Matematika Melalui Media Whatsapp Group Ditinjau Dari Hasil Belajar Mahasiswa ( Masa Pandemik Covid 19 ). 05(02), 65-74.

Yuangga, K. D., \& Sunarsi, D. (2020). Vol. 4 No. 3 Juni 2020. ( Kharisma Dan Denok, 2020 ), 4(3), 51-58. 